\title{
Characteristic of process flow in modular didactic production system for gear trains
}

\author{
Piotr JASKÓLSKI, Krzysztof NADOLNY
}

DOI: 10.30464/jmee.2019.3.2.115

Cite this article as:

Jaskólski P., Nadolny K. Characteristic of process flow in modular didactic production system for gear trains. Journal of Mechanical and Energy Engineering, Vol. 3(43), No. 2, 2019, pp. 115-120.

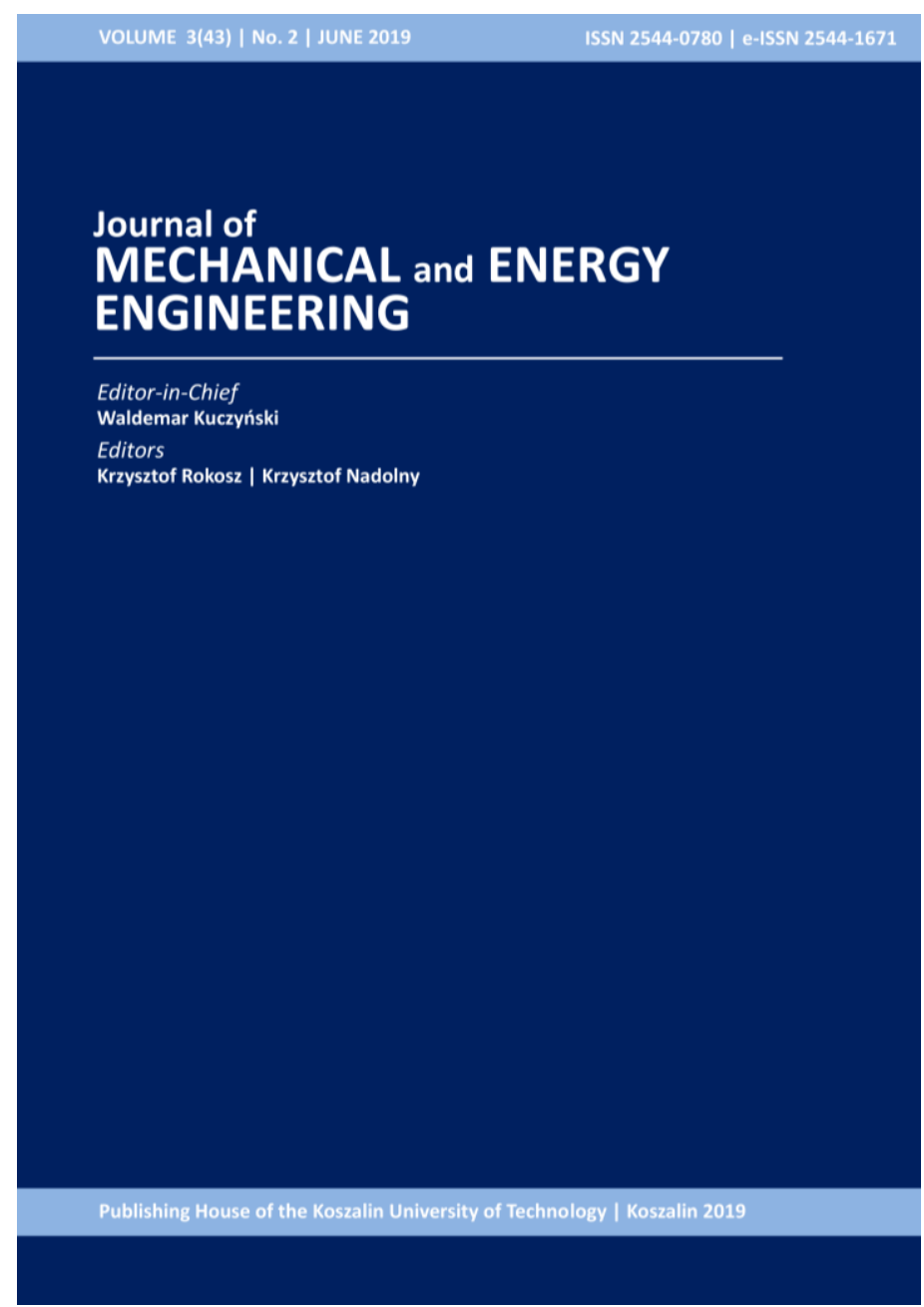

Journal of Mechanical and Energy

Engineering

Website: jmee.tu.koszalin.pl

ISSN (Print): 2544-0780

ISSN (Online): 2544-1671

Volume: 3(43)

Number: 2

Year: 2019

Pages: 115-120

Article Info:

Received 15 April 2019

Accepted 6 May 2019

\section{Open Access}

This article is distributed under the terms of the Creative Commons Attribution 4.0 (CC BY 4.0) International License (http://creativecommons.org/licenses/by/4.0/), which permits unrestricted use, distribution, and reproduction in any medium, provided you give appropriate credit to the original author(s) and the source, provide a link to the Creative Commons license, and indicate if changes were made. 


\title{
CHARACTERISTIC OF PROCESS FLOW IN MODULAR DIDACTIC PRODUCTION SYSTEM FOR GEAR TRAINS
}

\author{
Piotr JASKÓLSKI ${ }^{1 *}$, Krzysztof NADOLNY² \\ ${ }^{1 *}$ Faculty of Mechanical Engineering, Department of Production Engineering, Koszalin University \\ of Technology, Raclawicka 15-17, 75-620 Koszalin, Poland, e-mail: piotr.jaskolski@tu.koszalin.pl \\ ${ }^{2}$ Faculty of Mechanical Engineering, Department of Production Engineering, Koszalin University \\ of Technology, Raclawicka 15-17, 75-620 Koszalin, Poland, e-mail: krzysztof.nadolny@ tu.koszalin.pl
}

(Received 15 April 2019, Accepted 6 May 2019)

\begin{abstract}
The aim of the work was to create a technical and organizational design for a modular, didactic system for the production of single-stage gearing. The project presented a project of a production system equipped with miniaturized devices, which are commonly used in industry. Despite the reduced scale, the modules have full functionality and reflect the real world systems. Modular construction of the designed system allows for free modeling of production processes and creates great opportunities for future activities of system expansion and its use. Additionally, the system design assumes the possibility of carrying out scientific and research works in the scope of designing production systems with a high level of automation.
\end{abstract}

Keywords: modular production system, didactic production system, production system, production system, gearing, rapid prototyping

\section{INTRODUCTION}

Modular didactic production system (MDSP) is a production line whose aim is to physically simulate the production process of gears. The components of the system are a miniaturized form of equipment commonly used in industry. The applied systems, despite the reduced scale, fully reflect the real systems.

\subsection{Production programme}

During the design of production systems and processes, the volume of production, i.e. the so-called production program, is very important. The production program determines the number of pieces of elements that the plant is to produce within a specified time. The size of the production program is one of the most important factors that shape the character of the production process and which affects the amount of work that needs to be put into its development and implementation. Depending on the volume of production, the following types of production are distinguished [1]:

- unitary production in which individual products are manufactured that are not repeated or repeated indefinitely;

- serial production in which identical products in design and dimensions are produced in series or batches at specified intervals;

- mass production, which is the long-term production of identical products.

Table 1 shows the characteristics of the different types of production.

\subsection{Group machining in the design of manufacturing systems}

The aim of the group treatment method is to increase the seriality of small batches. This is achieved by identifying and grouping similar components of products according to their structural and technological similarity. Using this method, it is possible to produce even individual components in series production conditions [1]. 
Tab. 1. Characteristics of production types [2]

\begin{tabular}{cccc}
\hline Production & Mass & Serial & Unit \\
\hline Example of products & $\begin{array}{c}\text { Food, cosmetics, cars, } \\
\text { tyres, cars }\end{array}$ & $\begin{array}{c}\text { Books, shoes, clothes, } \\
\text { television sets, furniture }\end{array}$ & $\begin{array}{c}\text { Airplanes, ships, } \\
\text { generators }\end{array}$ \\
\hline $\begin{array}{c}\text { Communication } \\
\text { services, ATM } \\
\text { services }\end{array}$ & $\begin{array}{c}\text { University courses, tourist } \\
\text { excursions }\end{array}$ & $\begin{array}{c}\text { Computer program, } \\
\text { book writing }\end{array}$ \\
\hline Scale of production & Big & Medium (differentiated series) & Small (several or 1) \\
\hline $\begin{array}{c}\text { Product range } \\
\text { Frequency of product } \\
\text { changes }\end{array}$ & No (or very small) & Greater or lesser differentiation & Wide (not fixed) \\
\hline $\begin{array}{c}\text { Product } \\
\text { standardisation }\end{array}$ & High & Average & Very common \\
\hline $\begin{array}{c}\text { Machinery and } \\
\text { equipment }\end{array}$ & Specialist & Average & Low \\
\hline Employees & Low qualifications & Medium-Specialised & Universal \\
\hline
\end{tabular}

The group machining method is considered from the point of view of machining with conventional and numerically controlled machine tools. In the case of machining on conventional machine tools, the most important is the similarity of the shape of the elements in one group. The development of the technological process begins with the selection of one part, which will be the so-called representative of a given group. Most often, the element with the largest number of machining operations is selected. In this way, all elements with simpler shapes, which require fewer treatments, will be able to be performed without difficulty. On the other hand, on numerically controlled machine tools it is possible to perform much more operations than on conventional machine tools, so the similarity of shape of elements belonging to the same group does not matter much. There are no obstacles to obtaining different shapes on these machines, which may differ significantly from each other. Identifying and classifying similar elements into groups is facilitated by computer techniques. These groups are called part families. The grouping of elements in a family is used in the manufacturing process, in the product design process and in the design of production processes. The grouping concerns both the manufacture of elements and the assembly of products. Elements of similar dimensions do not always belong to the same family. This situation occurs when dimensional tolerances, material differences or production programs are different. This case is illustrated in Figure 1. Therefore, it is important to approach the grouping of parts with a great deal of sensitivity. In addition to technological and organisational knowledge, practice and intuition must also be available. The grouping method is the basis for designing and operating computer-aided production processes, i.e. systems such as Flexible Manufacturing System (FMS), Computer Aided
Design (CAD) and Computer Integrated Manufacturing Systems (CIM) [1].
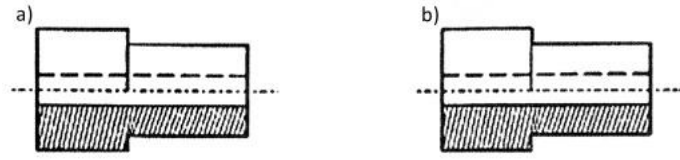

Fig. 1. Example of two similarly sized parts which are different due to their technological attributes: a) part $1 ;$ b) part 2 .

Tab. 2. Technological attributes of the parts shown in Figure 1

\begin{tabular}{lll}
\hline Technological attributes & Part 1 & Part 2 \\
\hline $\begin{array}{l}\text { Production programme } \\
\text { (pieces/year) }\end{array}$ & 100000 & 100 \\
\hline Performance tolerance & $\pm 0,015$ & $\pm 0,001$ \\
\hline Material & Stal 18-8 & bronze \\
\hline
\end{tabular}

\subsection{Production structure and trends in production}

The structure of a production process is a set of production cells in terms of object, technology or group technology, as well as a set of cooperative compounds occurring between them. They are created by grouping workstations into first-stage production cells, which merge into second-stage cells, etc., up to the n-stage cell, which corresponds to a given production unit.

When choosing the appropriate production structure, many factors should be taken into account, including the characteristics of complexity and type of manufactured products, properties and nature of technological processes, number and variety of production programs and assortment sizes, degree of specialization and cooperative relations of the 
production unit, characteristics of the involved workstations and limitations of production space.

Workstations in conventional production cells of lower levels are grouped in three main ways:

- groups of homogeneous stands (in technological terms), which contain machines and equipment fulfilling a similar function, enabling only a part of the production process of a product to be realized;

- groups of various workstations (in terms of subject matter) which contain machines and devices enabling the realisation of various partial processes;

- groups of various workstations (in terms of group technology) which enable the realization of the production process of a product or its closed fragment.

- by grouping workstations they are created:

- production nests, grouping together homogeneous or diverse workstations, which enable the production of different types of products;

- production lines that group together a variety of linearly arranged manufacturing or assembly stations of one or more types of products with linear spacing of workstations.

The production cells of the non-rhythmic production system are characterized by a high variability of both the assortment and the size of production programs. For this reason, production cyclograms and Gantt charts are used in the scheduling process. A production cycle is a certain type of schedule showing the course of processing and assembly of a product or a series of complex products. In turn, the Gantt schedule is a technique that enables the selection of the proper workload for the production cells of the non-rhythmic production system. These cells designed in subsequent stages require additional determination of supplementary factors, such as reserves of production capacity, stocks, shelving fields, or buffer warehouses, as well as determination of the form of payroll and workstation service [1].

\section{DESCRIPTION OF THE DIDACTIC MODULAR PRODUCTION SYSTEM}

The MDSP system consists of the following modules, which are numbered as shown in Figures 2 and 3 [3].

1. Component manufacturing station using the additive method for rapid prototyping of FDM.

2. The R1 robot arm is designed for the transport of components [5].

3. A rail for the R1 robot arm to extend its working range [5].

4. Quality control station for components and finished products.

5. Intermediate Product Warehouse.

6. S1 belt conveyor transporting elements from S1a to $\mathrm{S} 1 \mathrm{~b}$ [5].

7. R2 robot arm for transport and assembly [5].

8. assembly station.

9. S2 belt conveyor transporting elements from $\mathrm{S} 2 \mathrm{a}$ to $\mathrm{S} 2 \mathrm{~b}$ [5].

10. Pallet depot.

11. Warehouse for finished goods with a landfill site.

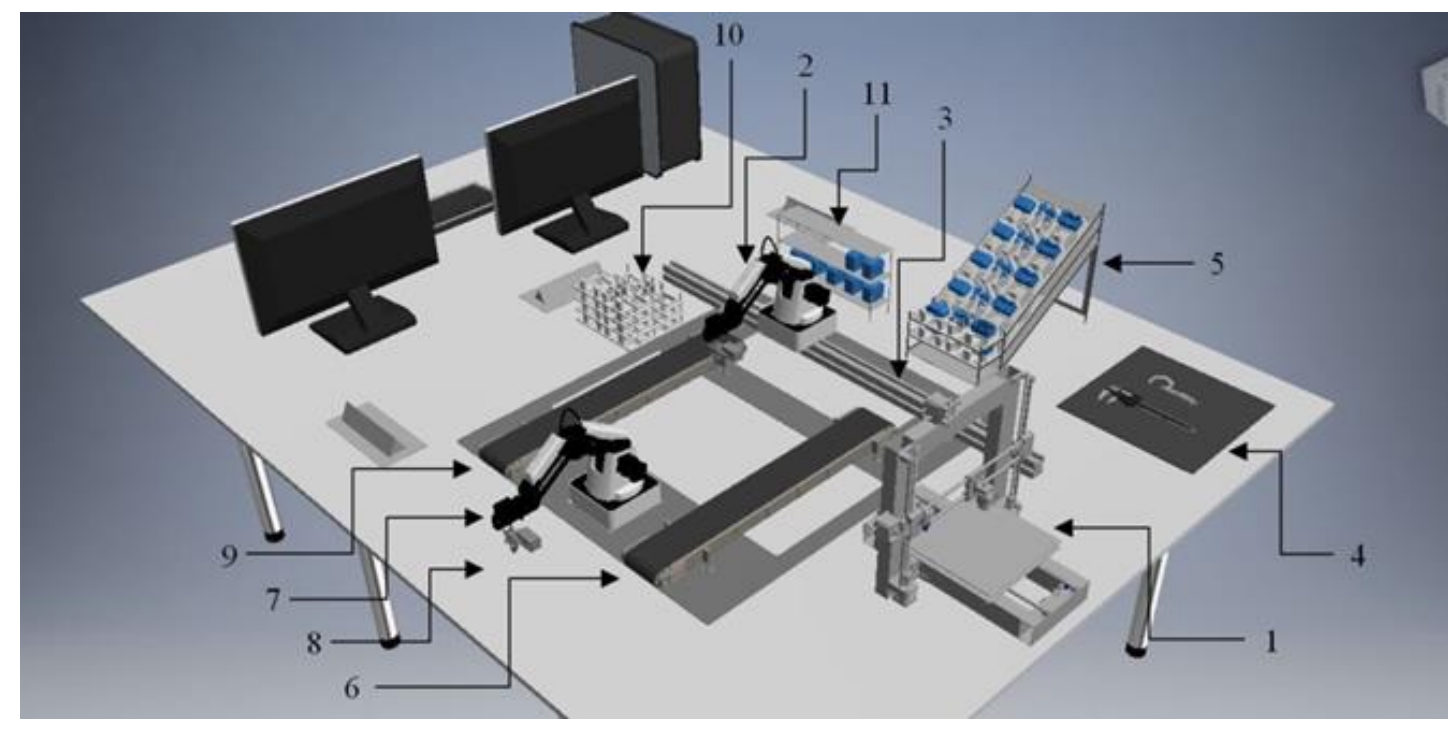

Fig. 2. Didactic, modular production system MDSP 


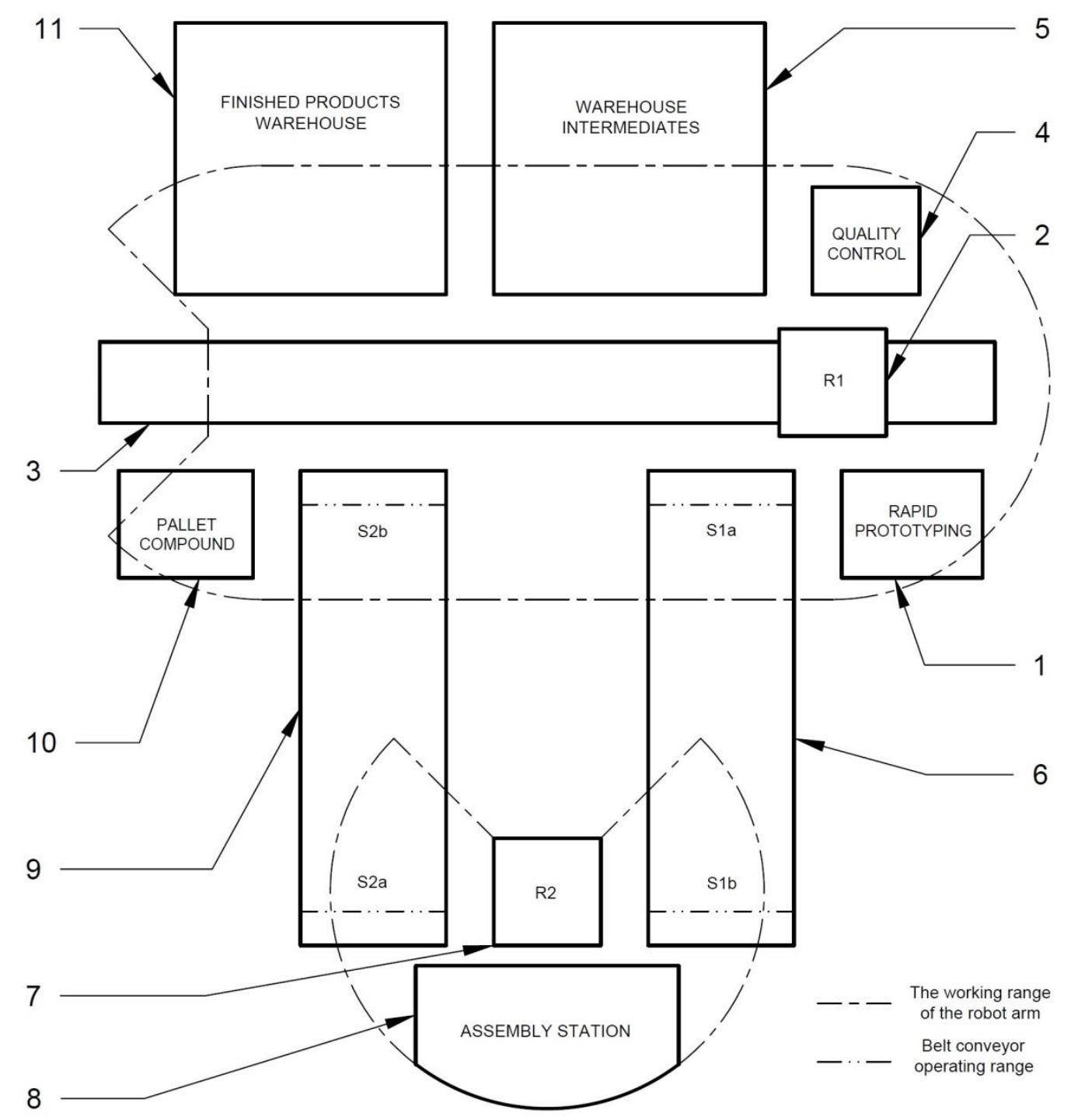

Fig. 3. Diagram of the MDSP single-stage gearing concept

\subsection{Description of the production process}

The production process in this system starts with the production of gear components using the additive method of rapid prototyping of FDM. After the manufacturing process is completed, the components are manually pulled out of the machine and the support material is removed from them. The components are then transferred to the quality control station, where the correctness and accuracy of their pressing is checked. If the elements do not meet the required quality requirements, they are transported to the production waste dump in the finished goods warehouse, and if the elements have been manufactured in accordance with the assumptions, they are palletized and stored in the semi-finished products warehouse. Figure 4 shows pallets with single-stage gearbox components stored in the semifinished products warehouse [3].

In the next stage, the robot arm R1 takes the pallet with the lower part of the gearbox split housing from the semi-finished products warehouse and transports it to the S1a point. Then the belt conveyor transports the pallet to $\mathrm{S} 1 \mathrm{~b}$, from where the robot frame R2 takes the lower part of the body to the assembly station (Figure 5). After placing the element, the robot arm R2 takes the empty pallet from S1b and moves it to $\mathrm{S} 2 \mathrm{a}$, from where it is transported by a conveyor belt to $\mathrm{S} 2 \mathrm{~b}$. Then the robot arm R1 takes the empty pallet from $\mathrm{S} 2 \mathrm{~b}$ and puts it in the pallet storage area. In the next stage, the described operations, from picking a pallet with a semi-finished product to storing an empty pallet, are repeated for pallets with other gearbox components [3]. 


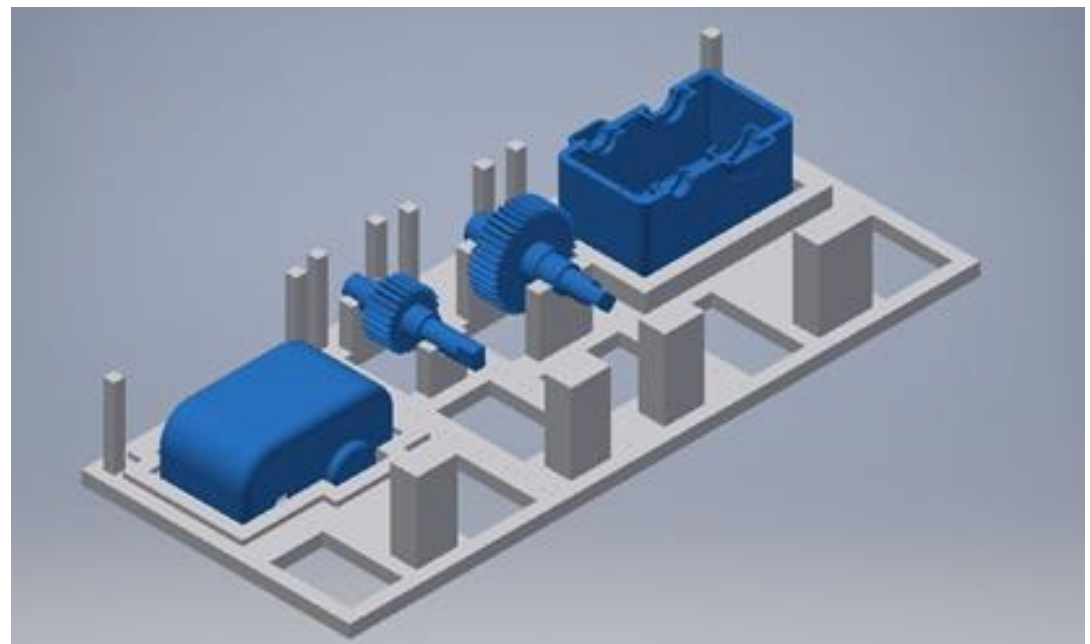

Fig. 4. Pallets with single-stage gearbox components

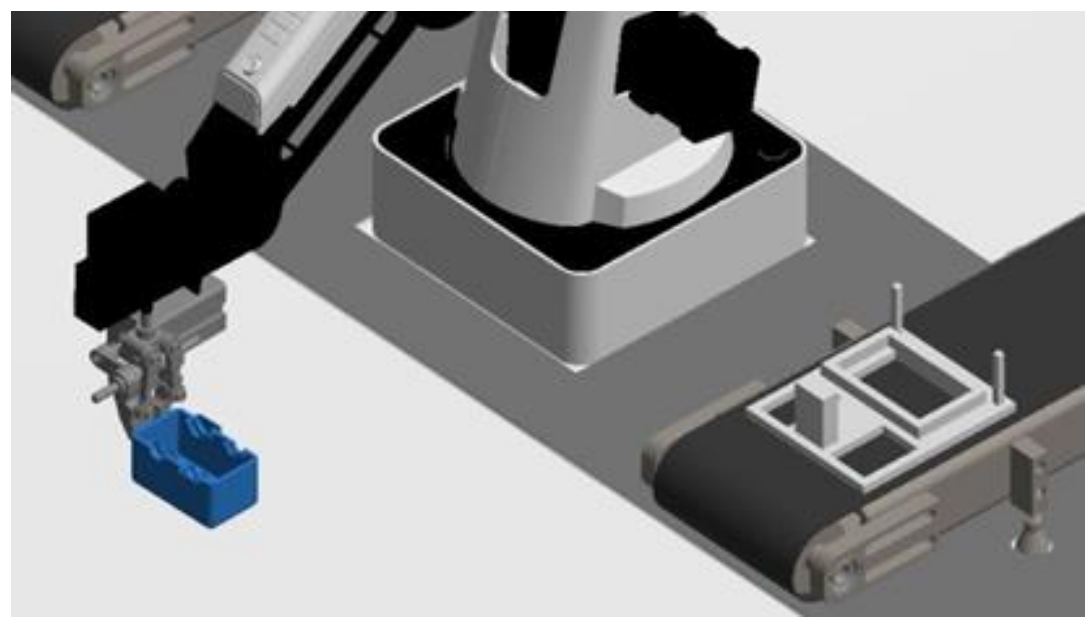

Fig. 5. Transporting the lower part of the housing of a single-stage gear unit to the mounting position

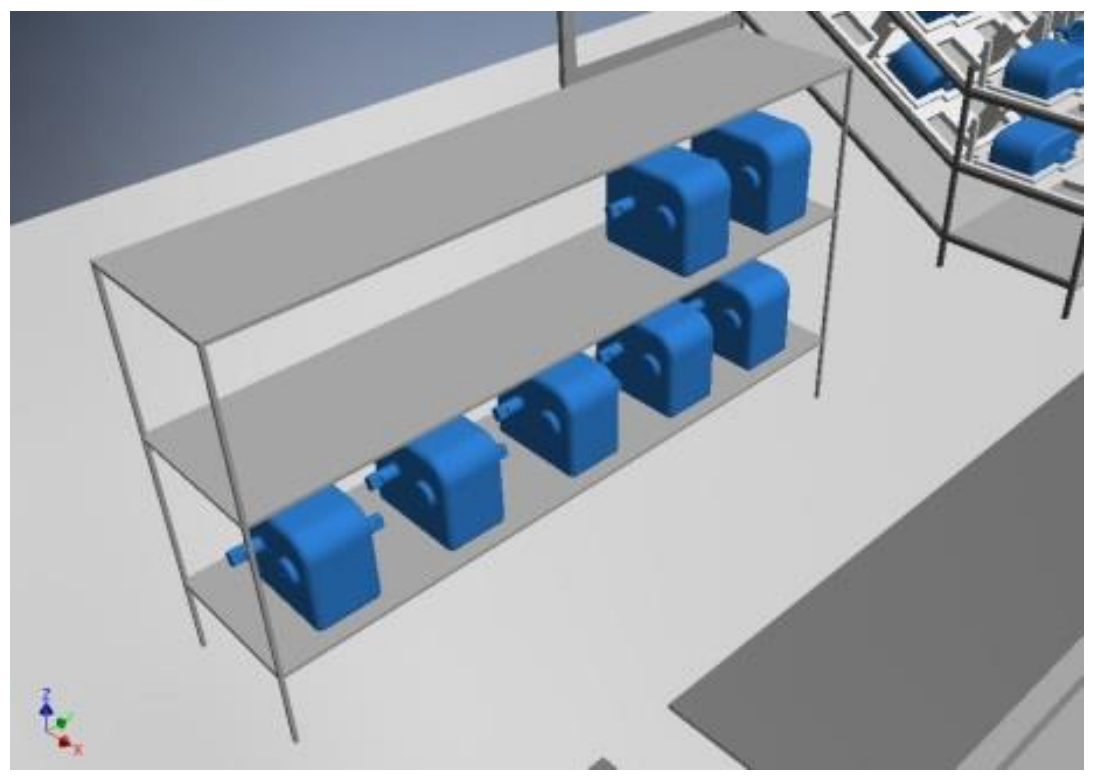

Fig. 6. Finished single-stage gearboxes in the finished goods warehouse 
Upon completion of the assembly operation, the complex single-stage transmission is picked up by the $\mathrm{R} 2$ robot arm, moved to $\mathrm{S} 2 \mathrm{a}$, then to $\mathrm{S} 2 \mathrm{~b}$, then picked up by the R1 robot arm and transported to the quality control station. This is where the correct assembly of the components is checked. If the gearbox is correctly assembled, the R1 robot arm moves it to the finished goods warehouse. However, if the elements are not assembled correctly, the defect is removed manually. When the defect turns out to be impossible to remove, the gearbox is transported to a waste dump in the warehouse of finished products, and when the defect is removed, the gearbox is stored in the warehouse of finished products. A schematic 3D digital model of the finished goods warehouse is presented in Figure 6 [3].

\section{CONCLUSIONS}

The following conclusions can be drawn from the process of manufacturing single-stage gearing in the MDSP system.

1. The presented system is characterized by a compact modular structure, which allows for the expansion of existing subsystems and allows for easy changeover of stands for new system projects.

2. All stations in the MDSP system have been arranged in such a way that they are within the working range of two manipulators.

3. The manually operated subsystems have been placed at the edges of the laboratory table, so that the operator has free access to them.

4. The use of a rail for the robot arm enabled seven MDSP workstations to be operated by one manipulator.

5. The main task of the second manipulator is the assembly of gears.

6. The use of two belt conveyors made it possible to carry out smooth, sequential transport of gear components to and from the assembly station.

7. By using an FDM device instead of conventional cavity techniques, the process of manufacturing single-stage gear components in MDSP was simplified.

8. The production of components is a narrow throat in the MDSP production process chain, so in order to streamline production, the number of FDM machines should be increased or higher capacity machines should be used.

\section{Nomenclature}

\author{
Acronyms \\ CAD - Computer Aided Design \\ CIM - Computer Integrated Manufacturing \\ FDM - Fused Deposition Modeling \\ FMS - Flexible Manufacturing System \\ MDSP - Modular Didactic Production System
}

\section{References}

1. Gawlik J., Plichta J., Świć A., 2013, Procesy produkcyjne, Polskie Wydawnictwo Ekonomiczne, Warszawa

2. Chlebus T., 2017, Istota zarządzania produkcją, Katedra Systemów Zarządzania, Politechnika Wrocławska, 13

3. Jaskólski P., 2018, Projekt techniczno-organizacyjny modułowego dydaktycznego systemu produkcji przekładni zębatych, Politechnika Koszalińska

4. Jaskólski P., 2019 Characteristic of didactic modular production systems, Journal of Mechanical and Energy Engineering

5. www.dobot.cc (access: January 2019)

\section{Biographical notes}

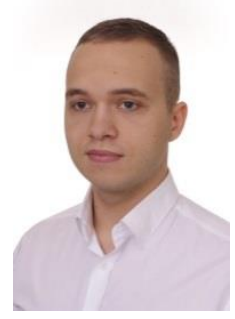

Piotr Jaskólski defended his diploma thesis with honors in 2018 at the Faculty of Mechanical Engineering of the Koszalin University of Technology, majoring in Management and Production Engineering, specializing in Computer Technology in Produ-ction Engineering. During his studies and diploma thesis he was the leader of a team of students performing a physical model of a modular didactic production system, leading to its launch and implementation into didactic classes in the field of Management and Production Engineering. Currently he is an employee of the Koszalin University of Technology at the Faculty of Mechanical Engineering. His scientific interests include issues related to automation of manufacturing processes and modern technologies in production engineering.

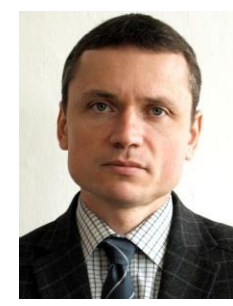

Krzysztof Nadolny received his M.Sc. degree in Mechanics and Machine Design and next Ph.D (with honors) as well as D.Sc. degree in Machinery Construction and Operation from Koszalin University of Technology, in 2001, 2006 and 2013, respectively. Since 2006 he has been a researcher in the Department of Production Engineering at the Koszalin University of Technology, where currently he works as an associated professor and head of research-didactic team for production planning and control. His scientific interests focus on problems concerning machining processes and tools, efficiency, monitoring and diagnostics of machining processes as well as tribology. $\mathrm{He}$ has participated in 2 international and 3 national research projects, presenting results of his work at 10 international and 21 national conferences, published more than 200 scientific papers in international and national journals, book chapters, as well as conference proceedings. He is also the author of 5 monographs and 13 national patents. 